\title{
Inhibition of Aspergillus flavus and Aflatoxin in Maize by Acorus calamus (Bojo)
}

\author{
PAURAKH THAPALIYA ${ }^{1 *}$, KUNDAN SHRESTHA ${ }^{2}$, BINAYA PRASAD SHRESTHA $^{2}$ and PASHUPATI MISHRA ${ }^{3}$
}

\author{
${ }^{1}$ College of Applied Food and Dairy Technology, Kathmandu, Nepal \\ ${ }^{2}$ Department of Food Technology and Quality Control, Babarmahal, Kathmandu \\ ${ }^{3}$ Central Campus of Technology, Hattisar, Dharan, Nepal
}

\begin{abstract}
This study was carried out to reveal the effect of Bojo powder on Aflatoxin production and growth of Aspergillus flavus 'ITCC 5192' in maize grain stored at four different moisture levels of 13, 17, 21 and 24\%. For the inhibition study, Bojo powder was used in the concentration of 0.0, 0.5, 0.75, 1.0, 1.25 and 1.5\% (w/w) in maize samples. After inoculation of Aspergillus flavus 'ITCC 5192' and incubation for 15 days, Aflatoxins were extracted and quantified by using Thin Layer Chromatography (TLC). Maize sample with moisture content $17 \%$ and Bojo powder concentration at $1.0 \%$ prevented the growth of Aspergillus flavus and production of Aflatoxin. Aflatoxins as high as 1416ppb were detected in control sample (i.e. no Bojo added) and stored at 17 and 21\% respectively. Formation of Aflatoxins and growth of Aspergillus flavus 'ITCC 5192'was not completely inhibited in maize grains at high moisture levels (i.e. 21 and 24\%).
\end{abstract}

Keywords: Aflatoxins, Aspergillus flavus, Bojo, TLC, Inhibition

\section{Introduction}

Maize is one of the most important grain crops produced in Nepal. In terms of area and production in Nepal, maize stands as second important crop (NARC, 2008). In the global production of cereal crops, maize ranks first after rice and wheat. Maize cultivation is a way of life for most farmers in the hills of Nepal. It is a traditional crop cultivated as food, feed and fodder on slopping Bari land (rainfed upland) in the hills. It is grown under rainfed conditions during the summer (April-August) as a single crop or relayed with millet later in the season. In the Terai, inner-terai, valleys, and low-lying river basin areas, maize is also grown in the winter and spring with irrigation. Improperly harvested and inadequately dried maize cobs can be infected by mould producing toxin. According to Karki et al., (1979) corn might be prominent problem area of Aflatoxin contamination especially during storage and movement of grains from the plain Terai to the deficit hilly area.

Aflatoxins are the most notorious of the Mycotoxins causing acute and chronic toxicity in animals and human and produce four distinct effects: acute liver damage; liver cirrhosis; tumor induction and teratogenesis (Smith and Moss, 1985). Outbreaks of aflatoxicosis in farm animals have been reported from many areas of the world. Aflatoxin contamination is also of prime concern in feed industry as low quality corn is used in the preparing poultry and animal feed. The species of the Aspergillus flavus group that produce Aflatoxins include $A$. flavus, A. parasiticus, A. nomius, A. tamarii and A. bombysis (Peterson et al., 2001). These fungi can grow on a wide range of agricultural commodities, the most important of which are maize and peanuts. Aflatoxins can be produced in preharvest as well as in stored products (Wilson and Payne, 1994).

* Corresponding author, E-mail: Paurakh.thapaliya@gmail.com
Natural compounds from plants have been used traditionally to preserve foods in countries like Japan, India, and Russia (Wilson and Wisniewski, 1992). The extracts and powders of some local plants show the ability to suppress the growth of toxicogenic fungi and hence toxin production in natural and synthetic media. Plant-produced compounds are becoming of interest as a source of safer and more effective substances than synthetically prepared antimicrobial agents. Essential oils of some plants have been reported as effective inhibitors of fungal growth and Aflatoxin production (Mahmoud, 1994). Current research investigates sweet flag's (Bojo) value as an insecticidal, antibacterial and antifungal agent (Motley, 1994). According to Entomology Division NARC, 1997-1998 and Ghosh, 2006 Bojo rhizomes and leaves possess insecticidal and fungicidal properties. In this context, the present study was undertaken in order to observe the effect of various concentration of Bojo (Acorus calamus) powder on the growth of A. flavus and Aflatoxin production when the fungi was grown was on maize grain of different moisture contents.

Aflatoxin contamination in maize is a worldwide problem. FAO estimates that $25 \%$ of world food crops are affected by Mycotoxins. For our country Nepal, it is an important issue because next to paddy, maize is the most grown cereal crop. Lack of knowledge regarding to harvesting technology, factors of contamination and lack of proper storage techniques and structures has further worsen this situation. Aflatoxin content in feed and feed ingredient is relatively higher because low quality cereals or damaged grains are usually used in preparing poultry and animal feed (Karki et al., 1979).Exposure to Aflatoxin is hazardous to human health. For that reason most countries have regulations governing the allowable concentration of Aflatoxin in food and feed. In Nepal, the guidance limit for total Aflatoxin of $20 \mathrm{ppb}(\mu \mathrm{g} / \mathrm{kg})$ for food is 
intended for human consumption. In this regard, work has to be done to minimize Aflatoxin contamination in maize and reduce potential health risk. The objective of this research was to study the effectiveness of Bojo rhizome powder (Acorus calamus) as a natural fungicide against toxicogenic mold Aspergillus flavus and inhibition of its harmful metabolite Aflatoxin in stored maize grain.

\section{Materials and Methods}

Collection of Bojo rhizomes and preparation of Bojo powder: Bojo rhizomes were obtained from Herbal House Production and Processing Company Limited, Branch Office, Hansposa, Tarahara. It was cleaned properly in tap water and prepared for its different forms to be used in the experiment. Cleaned Bojo rhizomes were cut in transverse section to obtain circular rings of thickness $2 \mathrm{~mm}$. Bojo pieces so obtained were dried in a cabinet drier at temperature of $50 \pm 5^{\circ} \mathrm{C}$ and $\mathrm{RH} 35$ $40 \%$ for 8 hours to obtain final moisture content of $5.54 \%$. It was then ground in an electric grinder and then screened through sieve having mesh size $300 \mu \mathrm{m}$. The grounded and sieved Bojo rhizome was stored in PET (Polyethylene Terephthalate) airtight containers under ambient conditions for further experimental procedures.

Collection of maize and adjustment of moisture content: Shelled maize of Rampur Composite variety was purchased from Agricultural Farm, Tarahara which is a branch office of NARC (Nepal Agricultural Research Council). The moisture content of maize as received was $10.5 \%$. Moisture content of maize was raised to desired level by the addition of water. The amount of water to be added to adjust the maize to different moisture content was calculated using the method and formula of Pixton, 1982.

Purchase of fungal culture: Pure Aspergillus flavus ITCC (Indian Type culture collection) 5192 used in the experiment was purchased from Indian Agricultural Research Institute, IARI, New Delhi, India.

Inoculation of fungal culture in maize grain: At first maize moisture contents were adjusted to $13 \%, 17 \%, 21 \%$ and $24 \%$ by the addition of sterile water according to formula and methods prescribed by Pixton 1982. Thus, there were four moisture levels. For each moisture level 6 samples were prepared. So, in total there were 24 samples. $500 \mathrm{~g}$ maize was taken in all 24 samples. Grains with no Bojo powder added served as control samples. All 24 samples were inoculated with a loop full of 5 days old mold spores grown on PDA plates.

\section{The treatments for 13\% moisture level were as follows;}

Grain with no Bojo added + mold culture $\left(\mathrm{S}_{11}\right)$

Bojo rhizome dust thoroughly mixed @ 2.50g per 500g of maize grain + mold spores $\left(\mathrm{S}_{12}\right)$

Bojo rhizome dust thoroughly mixed @ $3.75 \mathrm{~g}$ per 500g of maize grain + mold spores $\left(\mathrm{S}_{13}\right)$
Bojo rhizome dust thoroughly mixed @,5.0g per 500g of maize grain + mold spores $\left(\mathrm{S}_{14}\right)$

Bojo rhizome dust thoroughly mixed @6.25g per 500g of maize grain + mold spores $\left(\mathrm{S}_{15}\right)$

Bojo rhizome dust thoroughly mixed@7.5g per 500g of maize grain + mold spores $\left(\mathrm{S}_{16}\right)$

Similar treatments were given for maize with $17 \%$ moisture content and labeled as $\mathrm{S}_{21}, \mathrm{~S}_{22}, \mathrm{~S}_{23}, \mathrm{~S}_{24}, \mathrm{~S}_{25}$ and $\mathrm{S}_{26}$. Same treatments were given for maize with $21 \%$ moisture content and labeled as $\mathrm{S}_{31}, \mathrm{~S}_{32}, \mathrm{~S}_{33}, \mathrm{~S}_{34}, \mathrm{~S}_{35}$ and $\mathrm{S}_{36}$. Finally, similar treatments were given for maize with $24 \%$ moisture content and labeled as $\mathrm{S}_{41}, \mathrm{~S}_{42}, \mathrm{~S}_{43}, \mathrm{~S}_{44}, \mathrm{~S}_{45}$ and $\mathrm{S}_{46}$.

Samples for each moisture level were prepared at an interval of 2 days to facilitate Aflatoxin extraction. All samples were incubated at room temperature. Aflatoxins from each sample were extracted after 15 days of incubation.

Extraction of Aflatoxin from fungi inoculated maize samples and analysis: Aflatoxin extraction from the samples (representative 50g from each treatment) was according to the Plastic Minicolumn Method for Aflatoxin extraction as given by the method of Karunyavanij, (1981).

Quantification of Aflatoxin: For the quantification of Aflatoxin in the experimental samples, standard Aflatoxin solutions were prepared at first. 1mg Aflatoxin was dissolved in $100 \mathrm{ml}$ chloroform. Then further dilutions were made if necessary and exacted concentration of Aflatoxin standard solution was checked by spectrophotometer. The concentrations of standard solution used in the analysis were $\mathrm{AFB}_{1}$ of $1 \mu \mathrm{g} / \mathrm{ml}$ and $\mathrm{AFB}_{2}$ of $0.36 \mu \mathrm{g} / \mathrm{ml}$.

Preparation of TLC plates: TLC plates were prepared by mixing $40 \mathrm{~g}$ silica gel $\mathrm{G}$ containing $13 \% \mathrm{CaSO}_{4}$ as binder with $80 \mathrm{ml}$ water and pouring in plates of dimensions $0.5 \mathrm{~cm} \times 10 \mathrm{~cm} \times 20 \mathrm{~cm}$ or $0.5 \mathrm{~cm} \times 20 \mathrm{~cm} \times 20 \mathrm{~cm}$ and slided to 6 to 12 plates respectively to $0.5 \mathrm{~mm}$ thickness. These plates were then activated at $110^{\circ} \mathrm{C}$ for $1 \mathrm{hr}$.

Aflatoxin extracts of each samples subjected to analysis were dried at temperature of $60^{\circ} \mathrm{C}$ and diluted with $200 \mu 1$ of chloroform of grade A.R6. $5 \mu 1$ of each extracts were spotted on TLC plate of silica gel with acetone $+\mathrm{CHCl}_{3}(10+90)$ as eluting solvent. Spots were developed by spraying with sulphuric acid: distilled water (1:1). $\mathrm{AFB}_{1}$ and $\mathrm{AFB}_{2}$ concentrations were estimated by visual comparison of florescent intensity of sample spot in UV chamber (long wave length of $366 \mathrm{~nm}$ ) with that of the standards. If Aflatoxin is in high concentration, the extract was diluted.

Aflatoxins were analyzed using the above procedures in the lab of DFTQC (Department of Food Technology and Quality Control), Kathmandu.

Analytical procedure: Moisture content of maize was determined as per AOAC, (2005). Moisture content of fresh 
Bojo rhizome and dried Bojo powder were determined using Dean and Stark apparatus as per Ranganna (2001). Volatile oil and petroleum ether extract of Bojo were determined using Clevenger apparatus and Soxhelet apparatus as per Ranganna, (2001).

Statistical analysis: All the mean values were taken from triplicates. The experimental data were analyzed statistically for one way ANOVA using Genstat Discovery edition 3 software. The means were compared by LSD method at $5 \%$ level of significance.

\section{Results and Discussion}

Analysis of Bojo (Acorus calamus): The determined values of moisture content, volatile oil content and petroleum ether extract of Bojo presented in Table 1.

The findings closely resembled to those reported by (Mazza, 1985) on different species of Acorus calamus. The variations in volatile oil content, petroleum ether extract and moisture content can be the result of various factors like maturity of the rhizomes at harvesting, time of harvesting, place of growth and variation in the genetic species.

Table 1. Chemical analysis of Bojo

\begin{tabular}{lll}
\hline Parameters & \multicolumn{2}{c}{ Value* } \\
\cline { 2 - 3 } & Fresh rhizome & Bojo powder \\
Moisture content $(\%)$ & $74.52(0.057)$ & $5.54(0.017)$ \\
Volatile oil $(\%),(\mathrm{v} / \mathrm{w})$ & - & $1.6(0)$ \\
Petroleum ether extract $(\%),(\mathrm{w} / \mathrm{w})$ & - & $5.58(0.016)$ \\
\hline
\end{tabular}

* Means with standard deviations are in parenthesis

Inoculation of Fungal cultures in natural substrate (maize) and Aflatoxin analysis: Total Aflatoxin $\left(\mathrm{AFB}_{1}\right.$ and $\left.\mathrm{AFB}_{2}\right)$ in maize samples of different moisture contents and varying Bojo concentrations were estimated by TLC (Thin layer Chromatography) method (Figure 1).

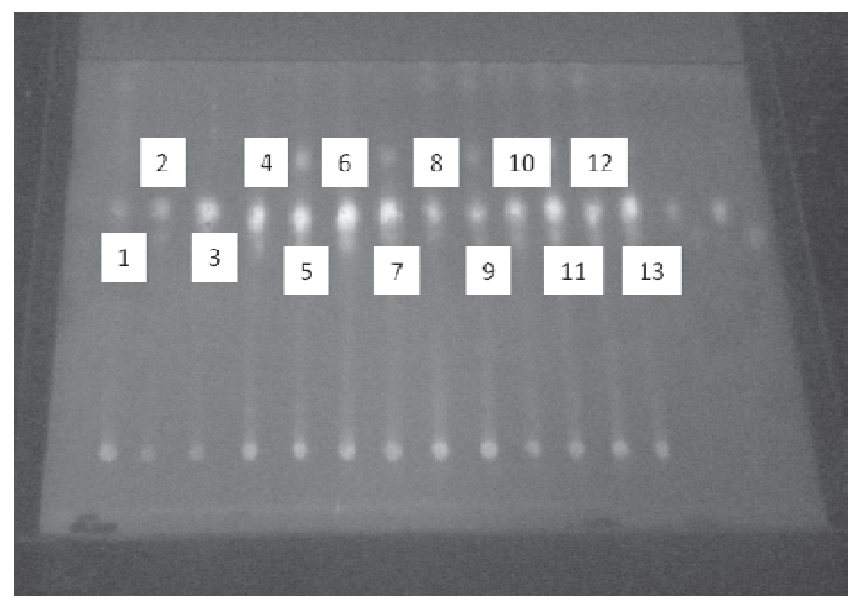

Figure 1. A typical TLC chromatogram

Note: 1. Standard Aflatoxin $B_{1}$ 2. Standard Aflatoxin $B_{2}, 3$. Sample $\mathrm{S}_{21}$, 4. Sample $\mathrm{S}_{22}$, 5. Sample $\mathrm{S}_{23}, 6$. Sample $\mathrm{S}_{24}, 7$. Sample $\mathrm{S}_{25}$, 8. Sample $\mathrm{S}_{26}$, 9. Sample $\mathrm{S}_{31}$, 10. Sample $\mathrm{S}_{32}, 11$. Sample $\mathrm{S}_{33}$, 12. Sample $\mathrm{S}_{34}, 13$. Sample $\mathrm{S}_{35}$.
No Aflatoxins were detected in samples of $13 \%$ moisture content with varying doses of Bojo powder. The mean values of total Aflatoxin produced in samples $\mathrm{S}_{21}, \mathrm{~S}_{22}$ and $\mathrm{S}_{33}$ were found to be 1416, 472 and 40ppb respectively whereas no Aflatoxins were detected in samples $\mathrm{S}_{24}, \mathrm{~S}_{25}$ and $\mathrm{S}_{26}$. Similarly, the mean values of total Aflatoxin produced in samples $S_{31}$, $\mathrm{S}_{32}, \mathrm{~S}_{33}, \mathrm{~S}_{34}, \mathrm{~S}_{35}$ and $\mathrm{S}_{36}$ were found to be $1416,1416,944,944$, 724.4 and $54.4 \mathrm{ppb}$ respectively. Similarly, the mean values of total Aflatoxin produced in samples $\mathrm{S}_{41}, \mathrm{~S}_{42}, \mathrm{~S}_{43}, \mathrm{~S}_{44}, \mathrm{~S}_{45}$ and $\mathrm{S}_{46}$ were found to be $724.4,724.4,537.6,188.8,188.8$ and $54.4 \mathrm{ppb}$.

Statistically, the effect of moisture content on the growth of Aspergillus flavus and total Aflatoxin production was significant $(\mathrm{p}<0.05)$. L.S.D showed that samples at moisture contents 13,17 and $21 \%$ were significantly different from one another whereas there was no significant difference between samples at 17 and $24 \%$ moisture contents in terms of total Aflatoxin production. Samples at 13 and 24\%; and 21 and $24 \%$ moisture contents were also significantly different from one another.

Statistically, the effect of various dosage of Bojo powder on the growth of Aspergillus flavus and toxin production was significant $(\mathrm{p}<0.05)$. LSD values showed that significant difference was observed between samples having Bojo concentration 0.0 and $0.5 \% ; 0.5$ and $0.75 \%$, whereas no significant differences were observed in total Aflatoxin production between samples having Bojo concentration 0.75 and $1.0 \% ; 0.75$ and $1.25 \% ; 1.0$ and $1.25 \%$ and 1.25 and $1.5 \%$. However, significant differences were observed between samples at 1.0 and $1.5 \% ; 0.75$ and $1.5 \% ; 0.0$ and $1.25 \% ; 0.0$ and $1.5 \% ; 0.5$ and $1.0 \% ; 0.5$ and $1.25 \%$ and 0.5 and $1.5 \%$.

Several researches have been conducted to determine the optimum temperature and moisture content of grains during storage to prevent Aspergillus spp. growth and Aflatoxin production. In maize inoculated with $A$. flavus and stored at $27^{\circ} \mathrm{C}$ for 30 days with varying moisture contents, an association between moisture content and Aflatoxin levels was established. At 16\% moisture, Aflatoxin levels reach $116 \mu \mathrm{g} / \mathrm{kg}$, while at $22 \%$ moisture, $2166 \mu \mathrm{g} / \mathrm{kg}$ Aflatoxin levels were obtained (Morena-Martinez et al., 2000)

Maize at $13 \%$ moisture content showed no Aflatoxin formation (Table 2) which strongly proves that such low moisture content does not support for A. flavus growth and toxin formation. In the case of Aflatoxin content, statistical differences were also observed. In treatments stored with high moisture content, Aflatoxin contamination increased.

Results showed that at maize moisture content $17 \%$, Bojo at or above concentration of $1 \%$ could prevent mold growth (Table 3 ) and toxin production whereas at higher moisture levels of $21 \%$ and $24 \%$ (table 4 and 5), Bojo powder at the concentrations used in the experiment could not prevent mold growth and toxin production. However, the amount of toxin produced decreased as concentration of Bojo powder was increased. 
Table2. Effect of Bojo concentration on Aflatoxin production at $13 \%$ moisture content

\begin{tabular}{llll}
\hline Concentration (\%) & $\begin{array}{c}\text { Aflatoxin } \\
\text { (AFB1) }\end{array}$ & $\begin{array}{c}\text { Aflatoxin } \\
\text { (AFB2) }\end{array}$ & Total Aflatoxin \\
\hline 0.0 & ND & ND & ND \\
0.5 & ND & ND & ND \\
0.75 & ND & ND & ND \\
1 & ND & ND & ND \\
1.25 & ND & ND & ND \\
1.5 & ND & ND & ND \\
\hline
\end{tabular}

*Values are the mean obtained from the triplicates, N.D: Not Detected. M.C: Moisture Content

Table3. Effect of Bojo concentration on Aflatoxin production at $17 \%$ moisture content

\begin{tabular}{llll}
\hline $\begin{array}{c}\text { Concentration } \\
(\mathbf{\%})\end{array}$ & $\begin{array}{c}\text { Aflatoxin(AFB1) } \\
\text { in ppb }\end{array}$ & $\begin{array}{c}\text { Aflatoxin(AFB2) } \\
\text { in ppb }\end{array}$ & $\begin{array}{c}\text { Total Aflatoxin } \\
\text { in ppb }\end{array}$ \\
\hline 0.0 & $1200 \pm 0.0^{\mathrm{a}}$ & $216 \pm 0.0^{\mathrm{a}}$ & $1416 \pm 0.0^{\mathrm{a}}$ \\
0.5 & $400 \pm 0.1^{\mathrm{b}}$ & $72 \pm 0.1^{\mathrm{b}}$ & $472 \pm 0.1^{\mathrm{b}}$ \\
0.75 & $40 \pm 0.2^{\mathrm{c}}$ & $\mathrm{ND}$ & $40 \pm 0.2^{\mathrm{c}}$ \\
1 & $\mathrm{ND}^{\mathrm{cd}}$ & $\mathrm{ND}$ & $\mathrm{ND}$ \\
1.25 & $\mathrm{ND}^{\mathrm{de}}$ & $\mathrm{ND}$ & $\mathrm{ND}$ \\
1.5 & $\mathrm{ND}^{\mathrm{cg}}$ & $\mathrm{ND}$ & $\mathrm{ND}$ \\
\hline *Values are the mean \pm S.D., with different superscripts $(\mathrm{a}, \mathrm{b}, \mathrm{c})$ in the same & \\
columns indicates significant difference (p<0.05)
\end{tabular}

Table4. Effect of Bojo concentration on Aflatoxin production at 21\% moisture content

\begin{tabular}{llll}
\hline $\begin{array}{c}\text { Concentration } \\
(\mathbf{\%})\end{array}$ & \multicolumn{1}{c}{$\begin{array}{c}\text { Aflatoxin } \\
\text { (AFB1) in ppb }\end{array}$} & $\begin{array}{c}\text { Aflatoxin (AFB2) } \\
\text { in ppb }\end{array}$ & $\begin{array}{c}\text { Total Aflatoxin } \\
\text { in ppb }\end{array}$ \\
\hline 0.0 & $1200 \pm 0.0^{\mathrm{a}}$ & $216 \pm 0.0^{\mathrm{a}}$ & $1416 \pm 0.0^{\mathrm{a}}$ \\
0.5 & $1200 \pm 0.0^{\mathrm{ab}}$ & $216 \pm 0.0^{\mathrm{ab}}$ & $1416 \pm 0.0^{\mathrm{ab}}$ \\
0.75 & $800 \pm 0.2^{\mathrm{c}}$ & $144 \pm 0.2^{\mathrm{c}}$ & $944 \pm 0.2^{\mathrm{c}}$ \\
1 & $800 \pm 0.3^{\mathrm{cd}}$ & $144 \pm 0.3^{\mathrm{cd}}$ & $944 \pm 0.3^{\mathrm{cd}}$ \\
1.25 & $640 \pm 0.1^{\mathrm{e}}$ & $84 \pm 0.1^{\mathrm{e}}$ & $724 \pm 0.1^{\mathrm{e}}$ \\
1.5 & $40 \pm 0.3^{\mathrm{f}}$ & $14 \pm 0.3^{\mathrm{f}}$ & $54 \pm 0.3^{\mathrm{f}}$ \\
\hline$*$ Values are the mean \pm S.D., with different superscripts $(\mathrm{a}, \mathrm{b}, \mathrm{c})$ in the same
\end{tabular}
columns indicates significant difference $(\mathrm{p}<0.05)$

Table5. Effect of Bojo concentration on Aflatoxin production at $24 \%$ moisture content

\begin{tabular}{llll}
\hline $\begin{array}{c}\text { Concentration } \\
(\%)\end{array}$ & $\begin{array}{c}\text { Aflatoxin (AFB1) } \\
\text { in ppb }\end{array}$ & $\begin{array}{c}\text { Aflatoxin (AFB2) } \\
\text { in ppb }\end{array}$ & $\begin{array}{c}\text { Total Aflatoxin } \\
\text { in ppb }\end{array}$ \\
\hline 0.0 & $640 \pm 0.0^{\mathrm{a}}$ & $84.4 \pm 0.0^{\mathrm{a}}$ & $724 \pm 0.0^{\mathrm{a}}$ \\
0.5 & $640 \pm 0.0^{\mathrm{ab}}$ & $84.4 \pm 0.2^{\mathrm{ab}}$ & $724 \pm 0.2^{\mathrm{ab}}$ \\
0.75 & $480 \pm 0.0^{\mathrm{c}}$ & $57.6 \pm 0.2^{\mathrm{c}}$ & $537 \pm 0.1^{\mathrm{c}}$ \\
1 & $160 \pm 0.0^{\mathrm{d}}$ & $28.8 \pm 0.0^{\mathrm{d}}$ & $188.8 \pm 0.0^{\mathrm{d}}$ \\
1.25 & $160 \pm 0.0^{\mathrm{de}}$ & $28.8 \pm 0.0^{\mathrm{de}}$ & $188.8 \pm 0.0^{\mathrm{de}}$ \\
1.5 & $40 \pm 0.2^{\mathrm{f}}$ & $14.4 \pm 0.2^{\mathrm{f}}$ & $54.4 \pm 0.2^{\mathrm{f}}$ \\
\hline
\end{tabular}

*Values are the mean \pm S.D., having different superscripts $(a, b, c)$ in the same columns indicates significant difference $(\mathrm{p}<0.05)$

The mean values of $A F B_{1}$ produced in samples $\mathrm{S}_{21}, \mathrm{~S}_{22}$ and $\mathrm{S}_{23}$ were found to be $1200 \mathrm{ppb}, 400 \mathrm{ppb}$ and $40 \mathrm{ppb}$ respectively whereas no $\mathrm{AFB}_{1}$ were detected in samples $\mathrm{S}_{24}, \mathrm{~S}_{25}$ and $\mathrm{S}_{26}$. Similarly, the mean values of $A_{F B}$ produced in samples $S_{31}$, $\mathrm{S}_{32}, \mathrm{~S}_{33}, \mathrm{~S}_{34}, \mathrm{~S}_{35}$ and $\mathrm{S}_{36}$ were found to be $1200,1200,800,800$, 640 and $40 \mathrm{ppb}$ respectively. Similarly, the mean values of $\mathrm{AFB}_{1}$ Produced in samples $\mathrm{S}_{41}, \mathrm{~S}_{42}, \mathrm{~S}_{43}, \mathrm{~S}_{44}, \mathrm{~S}_{45}$ and $\mathrm{S}_{46}$ were found to be $640,640,480,160,160$ and $40 \mathrm{ppb}$ respectively.
Statistically, the effect of moisture content on the growth of Aspergillus flavus and $\mathrm{AFB}_{1}$ production was significant $(\mathrm{p}<0.05)$. L.S.D showed that samples at moisture contents 13, 17 and $21 \%$ were significantly different from one another whereas there was no significant difference between samples at 17 and $24 \%$ moisture contents in terms of $\mathrm{AFB}_{1}$ production. Samples at 13 and 24\%; and 21 and 24\% were also significantly different $(\mathrm{p}<0.05)$ from one another in terms of $\mathrm{AFB}_{1}$ production.

Statistically, the effect of various dosage of Bojo powder on the growth of Aspergillus flavus and $\mathrm{AFB}_{1}$ production was significant $(\mathrm{p}<0.05)$. LSD values showed that significant difference were observed between samples having Bojo concentration 0.0 and $0.5 \% ; 0.5$ and $0.75 \% ; 0.0$ and $1.25 \% ; 0.5$ and $1.25 \% ; 0.75$ and $1.5 \% ; 0.0$ and $1.5 \%$ and 0.5 and $1.5 \%$. However, samples with Bojo concentration 0.75 and $1.0 \%$; 1.0 and $1.25 \%$ and 0.75 and $1.25 \%$ were not significantly different ( $\mathrm{p}>0.05)$ from one another in terms of $\mathrm{AFB}_{1}$ production (Table $2,3,4,5)$.

The mean values of $A_{F B}$ produced in samples $S_{21}$ and $S_{22}$ were found to be 216 and $72 \mathrm{ppb}$ respectively, whereas no $\mathrm{AFB}_{2}$ were detected in samples $\mathrm{S}_{23}, \mathrm{~S}_{24}, \mathrm{~S}_{25}$ and $\mathrm{S}_{26}$. Additionally, the mean values of $\mathrm{AFB}_{2}$ produced in samples $\mathrm{S}_{31}, \mathrm{~S}_{32}, \mathrm{~S}_{33}, \mathrm{~S}_{34}, \mathrm{~S}_{35}$ and $\mathrm{S}_{36}$ were found to be 216, 216, 144, 144, 84.4 and $14.4 \mathrm{ppb}$ respectively. Similarly, the mean values of $\mathrm{AFB}_{2}$ produced in samples $\mathrm{S}_{41}, \mathrm{~S}_{42}, \mathrm{~S}_{43}, \mathrm{~S}_{44}, \mathrm{~S}_{45}$ and $\mathrm{S}_{46}$ were found to be 84.4, 84.4, 57.6, 28.8, 28.8 and $14.4 \mathrm{ppb}$. Statistically, the effect of moisture content on the growth of $A$. flavus and $\mathrm{AFB}_{2}$ production were significant $(\mathrm{p}<0.05)$. LSD showed that samples at moisture contents 13,17 and $21 \%$ were not significantly different from one another whereas samples at moisture contents 17 and 24\% were not significantly different. Samples at moisture contents 13 and 24\%; and 21 and 24\% were also significantly different from one another in terms of $\mathrm{AFB}_{2}$ production.

Statistically, the effect of various dosage of Bojo powder on the growth of $A$. flavus and $\mathrm{AFB}_{2}$ production were significant $(p<0.05)$. LSD values showed that significant differences were observed between samples having Bojo concentration 0.0 and $0.5 \% ; 0.5$ and $0.75 \% ; 0.75$ and $1.5 \% ; 0.0$ and $1.5 \% ; 0.0$ and $1.0 \% ; 0.0$ and $1.25 \% ; 0.0$ and $0.75 \% ; 0.5$ and $1.0 \% ; 0.5$ and $1.25 \% ; 0.5$ and $1.5 \% ; 1.0$ and $1.5 \%$. However, the samples at Bojo concentration 0.75 and $1.0 \% ; 0.75$ and $1.25 \% ; 1.0$ and $1.25 \% ; 1.25$ and $1.5 \%$ were not significantly different $(\mathrm{p}>0.05)$ from one another in terms of $\mathrm{AFB}_{2}$ production (Table 2, 3, 4, 5).

Our results showed that Bojo powder at certain concentration could inhibit both growth and Aflatoxin production by Aspergillus flavus ITCC 5192. However, the dosage for controlling Aflatoxin producing fungi was higher in maize grain stored at higher moisture contents. Davidson and Parish, (1989) explained that in a food system such as maize grain, there are several factors that could affect the effectiveness of 
the compound, $\mathrm{pH}$ environments, lipids and decreased activity of hydrophobic compounds, and proteins that might cause binding of some compounds and reduce activity. Several previous and recent studies have described many important biological activities, particularly antimicrobial of $A$. calamus roots, rhizomes and essential oils (Grosvenor et al., 1995; Mungkornasawakul 2000; Mac Graw et al., 2002; Rani et al., 2003; Phongpaichit et al., 2005). A recent study by Phongpaichit et al., (2005) has revealed strong antimicrobial (antifungal and anti-yeast) properties of the crude methanol extract of $A$. calamus rhizome. In their study they found that methanol extract of rhizome exhibited high activity against filamentous fungi, Trichophyton rubrum, Microsporum gypseum and Penicillium marneffei. The sensitivity of the microorganism to the rhizome and leaf extract could be due to morphological as well as difference in the cell wall constitution of the microorganism tested. It is well established that á- and â-asarone found in leaf, roots and rhizome tissues are responsible for almost all the antimicrobial activities of the $A$. calamus (Mac Graw et al., 2002).

Dried Bojo powder as such is very effective antifungal agent and can be used to control $A$. flavus and Aflatoxin production in maize grains stored at or below $17 \%$ moisture contents in ambient conditions. It can be separated from the maize before milling by aspiration, sieving or washing operations that are performed during maize milling. But it has one drawback that it is not handy to use and can't be applied uniformly on the large scale.

\section{Conclusion}

Based on the results obtained from this study, at maize moisture content of $17 \%$ and Bojo powder concentration of $1 \%$ and above effectively prevented the growth of $A$. flavus as well as production of Aflatoxin in maize sample stored at ambient temperature.

The growth of $A$. flavus and toxin production was found to be moisture dependent. As per the experiment, maize sample containing $13 \%$ moisture did not support for the growth of $A$. flavus and Aflatoxin formation, whereas maximum Aflatoxin was detected at higher level moisture $(21 \%)$ maize. However, for moisture levels (i.e. $21 \%$ and 24\%), the higher the doses than that used in this experiment must be required, which seemed not be very practicable.

Due to the health and economic benefits of herbal plant materials may provide an alternative method to protect food and feed products from fungal contamination. In this regard, Bojo rhizome powder could be an effective natural fungicidal to inhibit the fungal growth and Aflatoxin production. Therefore, taking into the consideration of present findings, the performance of dried Bojo powder at concentration of $1 \%$ $(\mathrm{w} / \mathrm{w})$ or above was found to be a best natural fungicidal agent to control the growth of Aspergillus flavus ITCC 5192 and Aflatoxins production in maize sample containing lower moisture and stored at ambient condition.

\section{Reference}

AOAC (2005). Official Methods of Analysis of the Association of Official Analytical Chemist; $18^{\text {th }}$ edition.

Davidson P. M. and Parish M. E. (1989). Parish, Methods for testing the efficacy of food. Antimicrobials. Food Technol., 43:148-155.

Ghosh M. (2006). Antifungal properties of Haem Peroxidase from Acorus calamus, In:Annals of Botany, available online at: www.aob.oxfordjournals.org.

Grosvenor P. W., Suprino A Gray D. O. (1995). Medicinal plants from Rian province, Sumatra, Indonesia. Part 2: Antibacterial and antifungal activity. J. Ethnopharmacol 45: 97-111.

Karki T. B. and Sinha B. P. (1979). Mycotoxins contamination of foods and feeds in Nepal (C. F. R. L, Nepal).

Karunyavanij S. (1981). Plastic minicolumn for aflatoxin detection, http://www.fao.org/docrep/x5036e/ x5036E0h.htm

Mac Graw L. J., Jager A. K. and Van Staden J. (2000). Isolation of â-asarone, an antibacterial and antihelminthic compound, from Acorus calamus in South Africa. South African J. Bot., 68:31-35

Mahmoud A. L. E. (1994). Antifungal action and antiaflatoxigenic properties of some essential oil constituents. Lett. Appl. Microbiology, 110-113.

Mazza G. (1985). Gas Chromatographic and mass spectrometric studies of the constituents of the rhizome of calamus. I. The volatile constituents of essential oil. $J$. Chromatography, 328:179-194

Motley T. J. (1994). The Ethnobotany of Sweet Flag. Acorus calamus. Economic Botany, 48 (4): 397-412.

Mungkornasawakul P. (2000). Fungicide from Acorus calamus Linn. Eugenia Caryophyllus, Bullocket Harrison and Mammea Siamensis Kosterm and their residues after application. M.Sc. Thesis. Chiang Mai University, Chiang Mai.

Munkvold G., Hurburgh C. and Meyer J. (1999). Aflatoxins in corn. - In: Pest Management 1800, Cooperative Extension service, Iowa State University, Ames, IA, USA.

NARC (2008). Research Highlights, (2002/2003-2006-2007), Nepal Agricultural Research Council, Khumaltar, Lalitpur, Nepal, pp13-24. 
Pixton S. W. (1982). The importance of moisture and equilibrium relative humidity in stored products. Tropical stored product Information, pp 43-47.

Peterson S. W., Ito Y., Horn B.W. and Goto T. (2001). Aspergillus bombycis, a new alfatoxigenic species and genetic variation in its sibling species. A. Nomius, Mycolagia, 93: 689-703.

Phongpaichit S., Punenjob N., Rukachaisirikul V. and Ongsakul M. (2005). Antimicrobial activities of the crude methanol extract of Acorus calamus, J. Sci. Technol., 27 (suppl.2): 517-523.

Rani A. S., Satyakala M., Devi V. S and Murty U.S. (2003). Evaluation of antimicrobial activity from rhizome extract of Acorus calamus Linn. J. Sci. Indust. Res., 62-63.
Ranganna S. (2001). Handbook of Analysis and Quality Control for Fruits and Vegetable Products, $2^{\text {nd }}$ edn, Tata McGraw-Hill Publication., New Delhi.

Smith J.E. and Moss M.O. (1985). Mycotoxins Formation, Analysis and Significances Chichester: John Wiley \& sons.

Wilson C. L. and M. E. Wisniewski (1992). Further alternatives to synthetic fungicides for the control of postharvest diseases. In: Biological Control of plant diseases (E.T. Tjamos: Newyork: plenum press.

Wilson D. M. and Payne G. A. (1994). Factors affecting Aspergillus flavus group infection and Aflatoxin contamination of crops, In: The toxicology of Aflatoxin, Human health, Veterinary and Agricultural significance, (David L. Eaton and John D. Groopman, San Diego: Academic press. 